\title{
태국 최초로 ODA 공여관련 보고서 발표
}

1. 태국은 9.14 UN 세계정상회의에 즈음하여 OECD 국가들과 함께 UN천년개발목표(MDGs) 달성을 위한 자국의 기여도에 대한 보고서를 최초로 발표 한 바, 이에 따르면 태국은 2003년도에 GNI의 $0.13 \%$ 에 달하는 167 억불의 유 무상원조(ODA) 를 인근 라오스, 몰디브, 캄보디아, 미얀마 등에 공 여한 것으로 나타남.

2. 태국 외무부 보도자료(별첨) 및 당지 언론 보도에 따르면 태국의 전체 ODA 중 93\%는 최빈개도국 (LDC)에 지원되었고, 그 중의 대부분(전체의 $73 \%)$ 은 이른바 Baht화 경제권에 속하는 태국 인근의 라오스, 캄보디아, 미얀마에 대한 도로, 교량, 철 도, 공항 등 인프라 건설지원에 사용됨.

3. 태국은 현재 원조의 수혜국에서 원조 공여국으로 의 전환을 추진 중이며, 2004. 10. 18. 외교부 국제 경제기술국(DTEC)를 태국 국제협력단(TICA :
Thailand International Development Cooperation)으로 개편하고, OECD 개발원조위 원회(DAC)의 옵서버 가입을 신청하는 등 $\mathrm{OECD}$ 와의 관계 강화를 추진 중임.

[자료 : 주태국 대사관] 